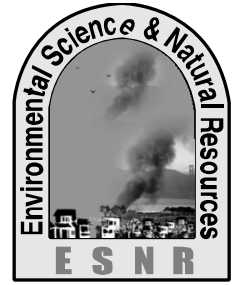

\title{
Physicochemical Parameters and Heavy Metal Concentration in Water at the Mokesh Beel of Bangladesh
}

\author{
P. C. Barmon, M. S. Islam* and M. H. Kabir \\ Department of Environmental Science and Resource Management \\ Mawlana Bhashani Science and Technology University, Tangail-1902, Bangladesh \\ *Corresponding author: islammstazu@yahoo.com
}

\begin{abstract}
The study investigated physicochemical parameters and heavy metal concentrations in water of the Mokesh beel during January to June 2016. Samples were collected from 3 different locations and analyzed in the laboratory of the Department of Environmental Science and Resource Management, MBSTU, Tangail and BINA, Mymensingh. Results showed that EC and TDS were varied from $645-688 \mu \mathrm{S} / \mathrm{cm}$ and $541-586 \mathrm{mg} / \mathrm{l}$, respectively indicated high ionic concentration, whereas DO of all stations ranged from $4.1-5.5 \mathrm{mg} / \mathrm{l}$ represents low organic waste, and $\mathrm{pH}$ (7.25-7.55) of all stations showed alkaline nature. In case of heavy metal concentration $\mathrm{Pb}, \mathrm{Cd}, \mathrm{Cu}, \mathrm{Zn}$ and $\mathrm{Cr}$ were within the standard level. The result concludes that the water can be used for different purposes but heavy metals can be accumulated in fish flesh, consequently affect the human health. To maintain the water quality and conserve the aquatic life, proper measures should be taken to prevent pollutants intrusion into the beel.
\end{abstract}

Key words: Aquatic environment, Heavy metal, Mokesh beel, Physicochemical parameter

\section{Introduction}

The surface water quality of the beel of Bangladesh is getting highly polluted day by day (Alam et al., 2007) with the rapid population growth, urbanization, haphazard agricultural and industrial production, all gives rise to increased levels of emissions of organic and inorganic pollutants into the aquatic environment (DoE, 1992). Industrial wastes are known to adversely affect natural life by direct toxic action or indirectly through qualitative alterations in the character of the water (Ahmed and Reazuddin, 2000). Recently, contamination of water with heavy metals is a major environmental concern; various anthropogenic activities continuously increase the amount of heavy metals in the water bodies especially in the beel, lakes, canals and rivers (Malik et al., 2010). Aquatic organisms such as fish and shell fish accumulate metals to concentrations many times higher than present in water or sediment (Olaifa et al., 2004). They can take up metals concentrated at different levels in their different body organs (Khaled, 2004). Certain environmental conditions such as salinity, $\mathrm{pH}$, and hardness can play an important role in heavy metals accumulation in the living organisms up to toxic concentrations and cause ecological damage (Guven et $a l .$, 1999). There are over 24000 registered small-scale industrial units in Bangladesh and it is generally accepted there were an equivalent number unregistered, furthermore, industrial growth has continued rapidly in the past decade, many of these industries are highly polluting and as a consequence of their unregulated development, many ecosystems are now under threat (SEHD, 1998).

The Mokesh beel is one of the biggest wetlands in the area covering approximately 1100 ha in the wet season, but holding only 40 ha of water in the dry season, when it receives most of its water from Ratanpur Khal, which is fed almost entirely by industrial effluent (BCAS, 2009). As a result, water quality has gradually deteriorated to a level which was reportedly unsuitable for certain types of aquatic life (IWRB, 1992).Dominant industries in the Mokesh beel area include textile production (dyeing, printing, and washing), large-scale commercial poultry farming, and pharmaceutical manufacturing. Industrial development in Mokesh beel, however, is not well managed. Most industries do not have an effluent treatment plan, and many that do have a plan have not implemented it because of cost (Akter, 2011). Moreover, the water quality in the Gazipur watershed exceeds one hundred percent due to industrial effluent and the daily effluent load is $37844 \mathrm{~kg}$ (IWM, 2007). This pollution was found to be a serious problem affecting the aquatic ecosystem and the local people reported that the fish they caught had a bad smell and were difficult to sell or eat (Akter, 2011). The aquatic environment for living organisms can be affected and bioaccumulation of harmful substances in the water- 
dependent food chain can occur. For this reason, the investigation of physicochemical parameters of water and heavy metal contamination in water of the Mokesh beel is essential since even slight changes in their concentration above the acceptable levels can result in serious environmental and subsequent human health problems.

\section{Materials and Methods}

\section{Study area}

The study was conducted in the Mokesh beel of the Gazipur district, Bangladesh, during the period from January to June 2016, covering the two villages namely Korolsurichala and Mediasulai, within the TuragBangshi wetland area of the Kaliakoir upazila (BBS, 2012). The study area was approximately located at $24.0750^{\circ} \mathrm{N}-90.2167^{\circ} \mathrm{E}$, and bounded by the Turag river to the north and east, Ratanpur khal to the south, and the Gazipur-square-Chandra-Kaliakor highway to the south and west (Akter, 2011).

\section{Sample collection}

The water samples were collected from 3different sampling stations of the Mokesh beel indicated as St-1 (Korolsurichala), St-2 (Mediasulai) and St-3 (TuragBangshi wetland area)during the dry season January to June 2016.To analyze the water quality, $500 \mathrm{ml}$ water was collected by plastic bottles with double stoppers from each sampling points. Before sampling, the bottle were cleaned and washed with detergent solution and treated with 5\% nitric acid $\left(\mathrm{HNO}_{3}\right)$ over night. The bottles were finally rinsed with deionized water and dried. At each sampling station, the sampling bottles were rinsed at least three times before sampling was done. Pre-prepared sampling bottles were immersed about $10 \mathrm{~cm}$ below the surface water. After sampling, the bottles were screwed carefully and marked with the respective identification number. The samples were acidified with $10 \%$ nitric acid $\left(\mathrm{HNO}_{3}\right)$, were placed in an ice bath and were brought to the laboratory. The samples were filtered through $0.45 \mu \mathrm{m}$ micro-pore membrane filter and were kept at freeze to avoid further contamination until analysis.

\section{Sample analysis}

The physicochemical parameters of water samples were analyzed in the laboratory of the Department of Environmental Science and Resource Management, Mawlana Bhashani Science and Technology University, Tangail. The water temperature and $\mathrm{pH}$ were determined by the thermometer and digital $\mathrm{pH}$ meter $(\mathrm{pH}$ Scan WP
1, 2; Malaysia), respectively. Digital EC and TDS meter (HM digital; Germany) was used to determine EC and TDS, respectively. The DO was determined by digital DO meter (D.46974; Taiwan). For analysis of heavy metal in water the prepared sample was taken in a vial and analyzed for $\mathrm{Pb}, \mathrm{Cu}, \mathrm{Cr}, \mathrm{Zn}$ and $\mathrm{Cd}$ by Atomic Absorption Spectrometer (AAS:AA-7000, Shimadzu, Japan) in the laboratory of the Bangladesh Institute of Nuclear Agriculture (BINA), Mymensingh, Bangladesh

\section{Statistical analysis}

The collected data were compiled and tabulated in proper form and were subjected to statistical analysis. The Microsoft Office Excel software was used to present and interpret the collected data. The results of the study were presented in charts and tabular forms.

\section{Results and Discussion}

\section{Physicochemical water quality parameters}

The highest temperature of the beel was $30.8^{\circ} \mathrm{C}$ at St-3 in April and the lowest was $23.3^{\circ} \mathrm{C}$ at St-2 in February, whereas the mean temperature of the Mokesh beel water was $27.36^{\circ} \mathrm{C}$ (Table 1). The standard limit of water temperature is $20-30^{\circ} \mathrm{C}$ (EQS, 1997) and the study showed that all the temperature was within the standard limit. The temperature ranged from $22.9-36.0^{\circ} \mathrm{C}$ along the Shitalakhya river in dry season during the sampling period where higher temperature was April, compared to February and March due to high air temperature (Alam et al., 2006), which is almost similar to the present study. The temperature ranged from $24.6-28.2^{\circ} \mathrm{C}$ at Ashulia point in the Turag river during the period from July to October (Khan et al., 2007).

The highest electrical conductivity (EC) of the beel water was $688 \mu \mathrm{S} / \mathrm{cm}$ at St-3 in February while the lowest was $645 \mu \mathrm{S} / \mathrm{cm}$ at St-1 in April with the mean temperature of the beel was $663 \mu \mathrm{S} / \mathrm{cm}$ (Table 1). The standard limit of $\mathrm{EC}$ in water is $700 \mu \mathrm{S} / \mathrm{cm}$ (EQS, 1997) and the study showed that all the EC contents were within the standard limit. According to DWASA (2011) the content of EC was ranged from $108-991 \mu \mathrm{S} / \mathrm{cm}$ at Kanchan and from $110-581 \mu \mathrm{S} / \mathrm{cm}$ at Kaligonj Kheyaghat in Shitalakhya River. According to Das et al. (2011), the EC of tannery effluent was $10455 \varepsilon S / \mathrm{cm}$ and in Buriganga and Karnatoli River were 614.5 and $175.6 \varepsilon S / \mathrm{cm}$, respectively. All these studies are relatively similar to the present study. 
The mean TDS content of the Mokesh beel water was $562 \mathrm{mg} / \mathrm{l}$, whereas the highest TDS content was $586 \mathrm{mg} / \mathrm{l}$ at Station-1 in February and the lowest was $541 \mathrm{mg} / \mathrm{lat}$ Station-2 in March. The standard limit of TDS in water is $1000 \mathrm{mg} / \mathrm{l}$ (ADB, 1994) and the study showed that all the TDS contents were within the standard limit. The TDS contents of different sampling points of Turag River were ranged from 100-580mg/l (Rahman et al., 2012). The TDS concentrations of the Padma river water ranged from 129-166, 118-140 and 147-178mg/l over the premonsoon, monsoon and post-monsoon, respectively (Islam et al., 2014), and all these studies are similar to the present study.

Table 1. Water quality parameters of the Mokesh beel

\begin{tabular}{|c|c|c|c|c|c|c|}
\hline \multirow{2}{*}{ Parameters } & \multirow{2}{*}{$\begin{array}{c}\text { Sampling } \\
\text { stations }\end{array}$} & \multicolumn{3}{|c|}{ Months } & \multirow{2}{*}{ Mean } & \multirow{2}{*}{ Standard } \\
\hline & & February & March & April & & \\
\hline \multirow{3}{*}{ Temp. $\left({ }^{\circ} \mathrm{C}\right)$} & St-1 & 23.5 & 27.8 & 30.5 & 27.26 & \multirow{3}{*}{$\begin{array}{c}20.0-30.0 \\
(E Q S, 1997)\end{array}$} \\
\hline & St-2 & 23.3 & 28.1 & 30.7 & 27.37 & \\
\hline & St-3 & 23.6 & 27.9 & 30.8 & 27.43 & \\
\hline \multirow{3}{*}{$\mathrm{EC}(\varepsilon S / \mathrm{cm})$} & St-1 & 684 & 653 & 645 & 660 & \multirow{3}{*}{$\begin{array}{c}700 \\
(\mathrm{EQS}, 1997)\end{array}$} \\
\hline & $\mathrm{St}-2$ & 687 & 657 & 655 & 666 & \\
\hline & St-3 & 688 & 656 & 649 & 664 & \\
\hline \multirow{3}{*}{ TDS (mg/l) } & St-1 & 586 & 543 & 557 & 562 & \multirow{3}{*}{$\begin{array}{c}1000 \\
(\mathrm{ADB}, 1994)\end{array}$} \\
\hline & $\mathrm{St}-2$ & 580 & 541 & 562 & 562 & \\
\hline & St-3 & 578 & 544 & 568 & 563 & \\
\hline \multirow{3}{*}{$\mathrm{DO}(\mathrm{mg} / \mathrm{l})$} & St-1 & 4.6 & 5.3 & 4.1 & 4.7 & \multirow{3}{*}{$\begin{array}{c}5.0 \\
(\mathrm{EQS}, 1997)\end{array}$} \\
\hline & $\mathrm{St}-2$ & 4.3 & 5.4 & 4.8 & 4.8 & \\
\hline & St-3 & 4.8 & 5.5 & 4.7 & 5.0 & \\
\hline \multirow{3}{*}{$\mathrm{pH}$} & St-1 & 7.25 & 7.53 & 7.41 & 7.40 & \multirow{3}{*}{$\begin{array}{c}6.50-8.50 \\
(\mathrm{ECR}, 1997)\end{array}$} \\
\hline & $\mathrm{St}-2$ & 7.43 & 7.54 & 7.48 & 7.48 & \\
\hline & St-3 & 7.48 & 7.55 & 7.47 & 7.50 & \\
\hline
\end{tabular}

The highest DO content of the beel water was observed $5.5 \mathrm{mg} / \mathrm{l}$ at St-3 in March while the lowest was $4.1 \mathrm{mg} / \mathrm{l}$ at St-1 in April, whereas the mean DO content was $4.8 \mathrm{mg} / 1$ (Table 1). The standard limit of DO is $5.0 \mathrm{mg} / \mathrm{l}$ (EQS, 1997) and the study showed that most of the DO contents were lower than the standard might be due to the presence of organic waste into the water (Islam et al., 2014). The DWASA (2011) reported that the contents of DO ranged from 1.5-6.2mg/l at Kanchan and 4.0-7.4mg/l at Kaligonj Kheyaghat in Shitalakhya river, which is almost similar to the present study. The mean DO content of the Padma river water were found 7.31, 7.59 and $6.82 \mathrm{mg} / \mathrm{l}$ over pre-monsoon, monsoon and postmonsoon, respectively (Islam et al., 2014).

The highest $\mathrm{pH}$ was 7.55 at St-3 in March and the lowest was 7.25at St-1 in February, with the mean pH was 7.46 (Table 1). The standard limit of $\mathrm{pH}$ is 6.5-8.5 (ECR, 1997) and the study showed that almost all recorded $\mathrm{pH}$ was within the standard limit. The result of the study revealed that the beel water tends to be alkaline, this may be due to the alkali contain waste and effluent into the water and heavy rainfall. Alam et al. (2004) found that the $\mathrm{pH}$ was 7.5 in rainy season and 7.4 in dry season at Demraghat in Shitalakhya River. The $\mathrm{pH}$ of Padma river water were ranged from 7.0-7.6, 7.61-8.20 and 7.5-7.8 over the pre-monsoon, monsoon and post- monsoon, respectively (Islam et al., 2014), all these studies are almost similar to the present study.

\section{Heavy metals concentration in water}

The study showed that the highest concentration of lead $(\mathrm{Pb})$ of the Mokesh beel water was $0.0019 \mathrm{mg} / \mathrm{l}$ at sampling St-1in April and the lowest was $0.0010 \mathrm{mg} / \mathrm{l}$ at St-1 in March (Fig. 1), whereas the standard of $\mathrm{Pb}$ in water is $0.05 \mathrm{mg} / \mathrm{l}(\mathrm{ECR}, 1997)$ and all the investigated concentrations were lower than the standard indicated that the water was not polluted by $\mathrm{Pb}$ containing 
compounds. The concentration of $\mathrm{Pb}$ ranged from $0.00269-0.00589 \mathrm{mg} / \mathrm{l}$ at Ashulia point in the Turag river (Rahman et al., 2012) which is almost similar to the present study.

The study stated that the highest concentration of cadmium $(\mathrm{Cd})$ of the beel water was $0.0019 \mathrm{mg} / \mathrm{l}$ at sampling St-3in April and the lowest was $0.0012 \mathrm{mg} / \mathrm{l}$ at St-1and St-2 in March and February (Fig. 2), respectively. The standard of $\mathrm{Cd}$ in water is $0.005 \mathrm{mg} / \mathrm{l}$ (ECR, 1997) and all the recorded concentrations were lower than the standard indicated that the water was not highly polluted by $\mathrm{Cd}$ containing compounds. Ahmad et al. (2010) studied that the concentration of $\mathrm{Cd}$ ranged from $0.007-0.012 \mathrm{mg} / 1$ during monsoon and postmonsoon season in Buriganga River. The concentration of $\mathrm{Cd}$ was below detection level in Gulshan lake, Bangladesh (Quraishi et al., 2010); all these studies are almost similar to the present study.
The study depicted that the highest concentration of copper $(\mathrm{Cu})$ was $0.08 \mathrm{mg} / \mathrm{l}$ at $\mathrm{St}-2$ in April and the lowest was $0.02 \mathrm{mg} / \mathrm{l}$ at St-2 in February (Fig. 3), whereas the standard of $\mathrm{Cu}$ in water is $1.00 \mathrm{mg} / \mathrm{l}(\mathrm{ECR}, 1997)$ and all the concentrations were lower than the standard. The collected surface water samples from the Turag river contained significant amount of $\mathrm{Cu}$ and ranged from $0.01-0.02,0.02-0.03$ and $0.21-0.27 \mathrm{mg} / 1$ during postmonsoon, pre-monsoon and monsoon season, respectively (Meghla et al., 2013) which is almost similar to the present study. The concentration of $\mathrm{Cu}$ ranged from $0.028-0.043 \mathrm{mg} / 1$ at Ashulia point in the Turag River during the period from July to October (Khan et al., 2007).

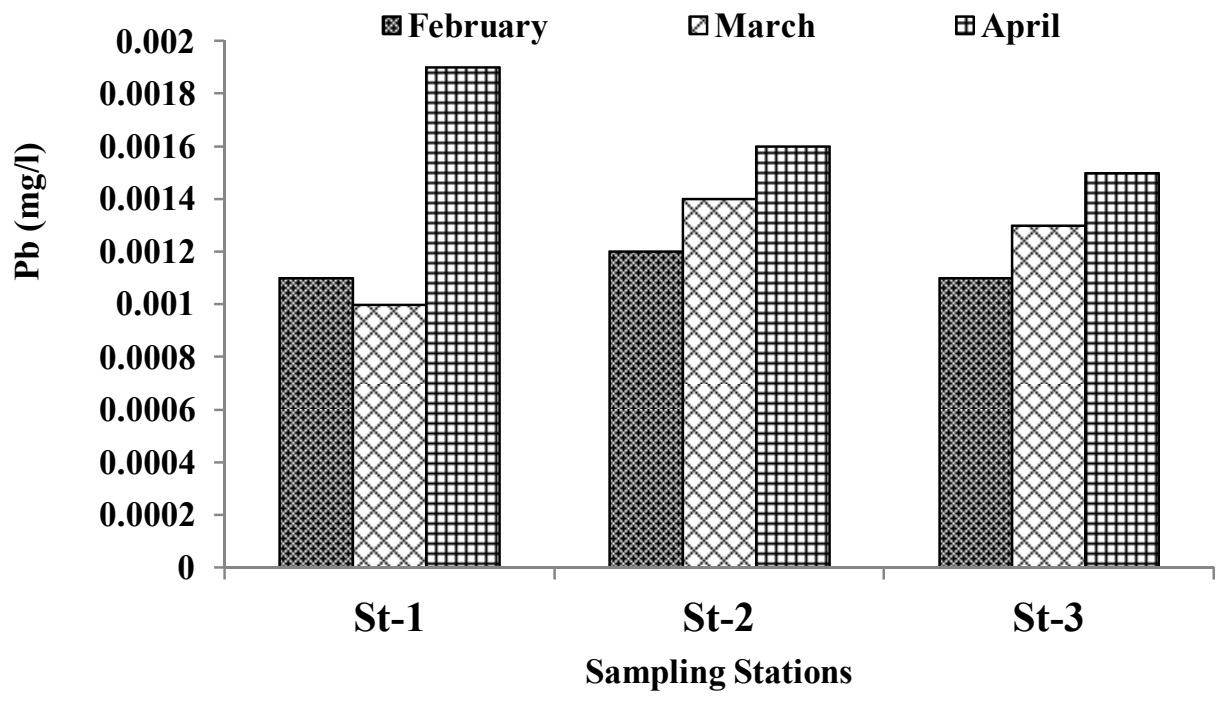

Fig. 1. Lead concentration $(\mathrm{mg} / \mathrm{l})$ in water of the Mokesh beel 


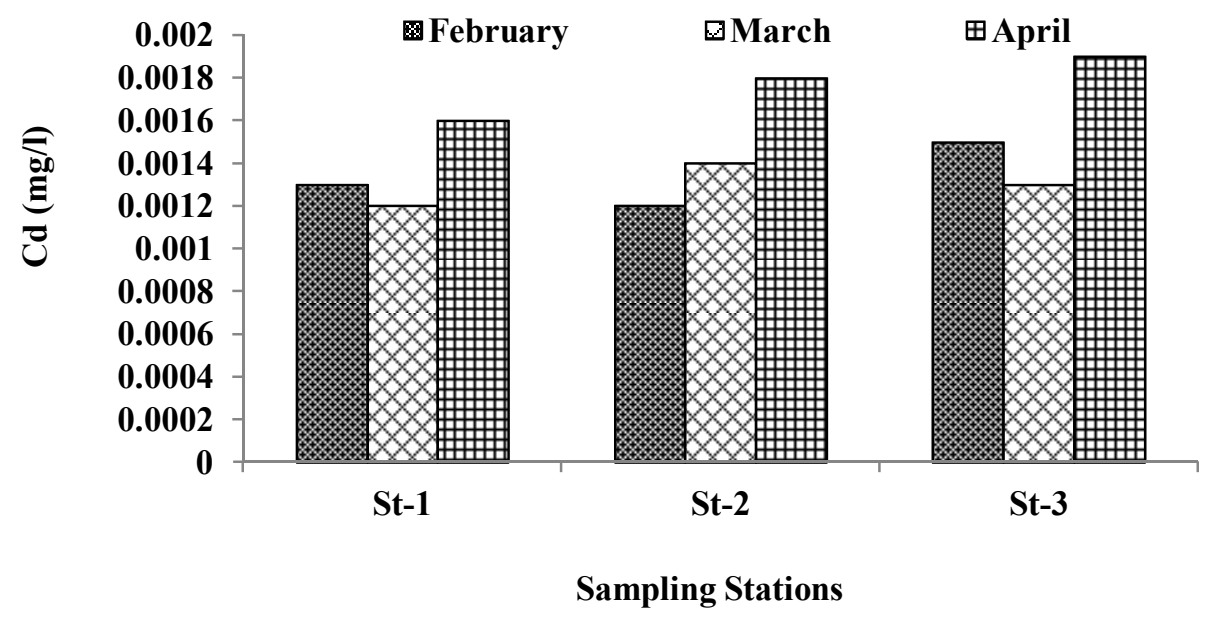

Fig. 2. Cadmium concentrations (mg/l) in water of the Mokesh beel

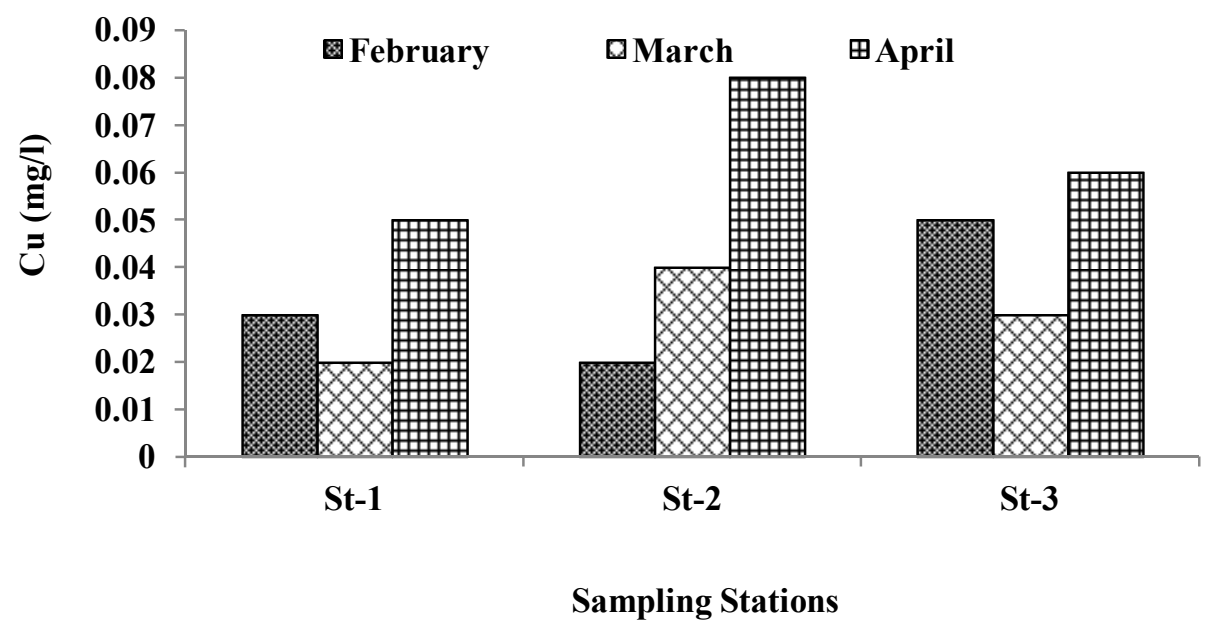

Fig. 3. Copper concentrations (mg/l) in water of the Mokesh beel

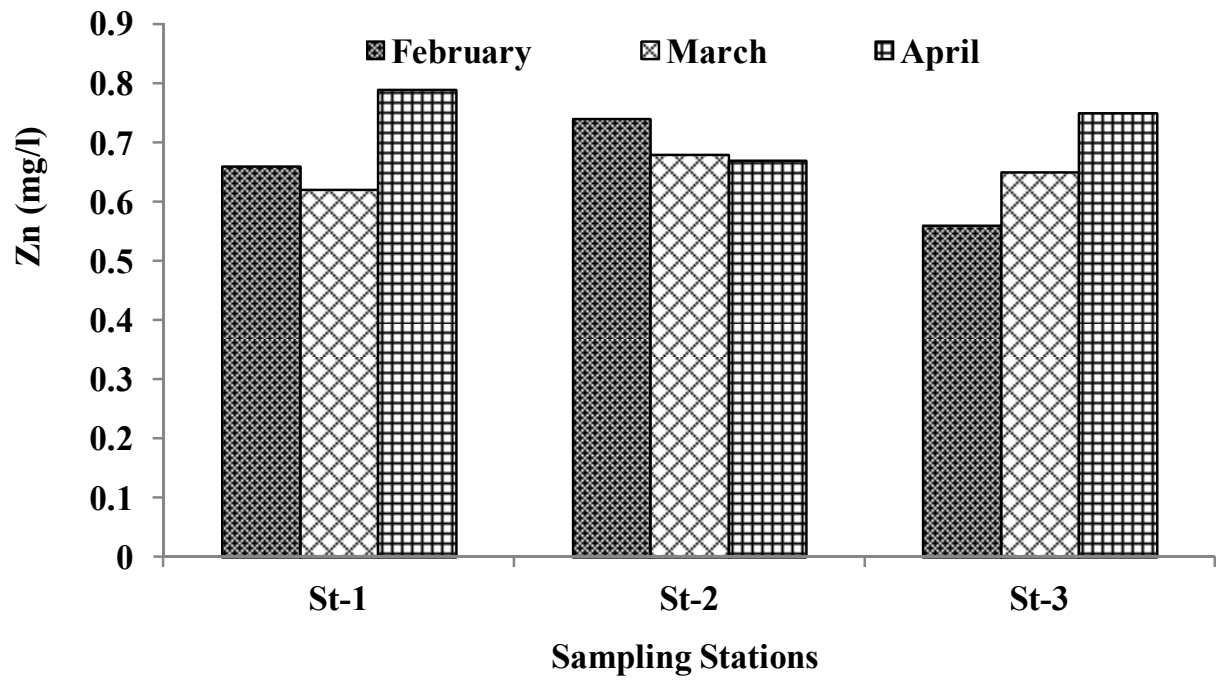

Fig. 4. Zinc concentrations $(\mathrm{mg} / \mathrm{l})$ in water of the Mokesh beel 
The study revealed that the highest concentration of zinc (Zn) in beel water was $0.79 \mathrm{mg} / \mathrm{l}$ at sampling St-1 in April while the lowest was $0.56 \mathrm{mg} / \mathrm{l}$ at St-3 in February (Fig. 4). The standard of $\mathrm{Zn}$ in water is $5.00 \mathrm{mg} / \mathrm{l}$ (ECR, 1997) and the all investigated concentrations were lower than the standard levels indicated that the water was not highly polluted by $\mathrm{Zn}$ containing compounds. The status of $\mathrm{Zn}$ contaminations of river water of Dhaka Metropolitan City was $0.021 \mathrm{mg} / \mathrm{l}$ (Mokaddes et al., 2013). Begum (2005) investigated the water pollution of Mauna and Mouchak industrial areas of Gazipur district and reported that the concentration of $\mathrm{Zn}$ in industrial effluents was within the range of $0.01-3.60 \mathrm{mg} / \mathrm{l}$.

The study showed that the highest concentration of chromium $(\mathrm{Cr})$ in beel water was $0.019 \mathrm{mg} / \mathrm{l}$ at sampling
St-3 in April whereas the lowest value was $0.015 \mathrm{mg} / \mathrm{l}$ at St-1 in February (Fig. 5), while the standard of $\mathrm{Cr}$ in water is $0.05 \mathrm{mg} / \mathrm{l}(\mathrm{ECR}, 1997)$ and all the recorded concentrations were lower than the standard levels indicating that the water was not highly polluted by $\mathrm{Cr}$ containing compounds. Mohuya et al. (2010) studied on Gulshan-Baridhara lake, Bangladesh, and they found that the mean concentration of $\mathrm{Cr}$ in summer was $0.10 \mathrm{mg} / \mathrm{l}$ and the mean concentration of $\mathrm{Cr}$ in monsoon was $0.018 \mathrm{mg} / \mathrm{l}$. The minimum $\mathrm{Cr}$ concentration was noted from the water sample at Demraghat $0.052 \mathrm{mg} / 1$ (Sumon, 2012). The concentration of total chromium in water samples in Buriganga river of Bangladesh were greatly exceeded the toxicity reference values in both season (Mohiuddin et al., 2010).

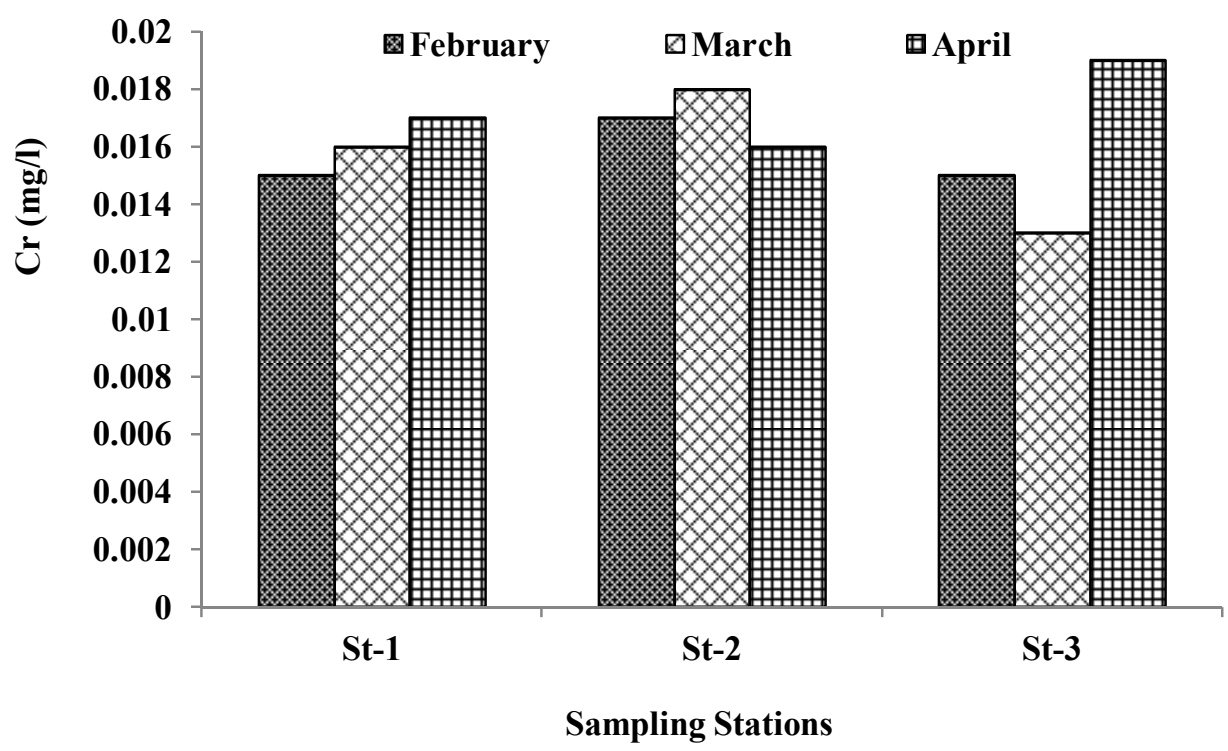

Fig. 5. Chromium concentrations $(\mathrm{mg} / \mathrm{l})$ in water of the Mokesh beel

\section{Conclusion}

From the overall discussions, it can be concluded that the quality of water in the Mokesh beel is suitable for utilizing in various purposes especially for fisheries. But though it already not hampers the aquatic lives and also the lives of adjacent people, the present status should not let continue that may get critical in near future. In order to achieve the suitable water quality for common uses and for conserving the ecosystem, proper measures should be taken to prevent the water pollution of the beel. To maintain sound environment and healthy ecosystem of the beel and the surrounding areas, identification of illegal industries set up on the bank of the beel, set up of effluent treatment plant (ETP) for all industries, strict legislation for dumping of wastewater into the beel, raising awareness among local people about the water pollution and their adverse effects on public health.

\section{Acknowledgement}

Sincere gratitude due to Dr. Iqbal Bahar (Assistant Registrar, Lab), Department of Environmental Science and Resource Management, Mawlana Bhashani Science and Technology University, Tangail-1902, Bangladesh, for his nice cooperation during the study period. 


\section{References}

ADB (Asian Development Bank). 1994. Training manual for environmental monitoring. Engineering Science Inc., USA.pp.2-16.

Ahmad, M. K., S. Islam, S. Rahman, M. R. Haque and M. M. Islam. 2010. Heavy metals in water, sediment and some fishes of the Buriganga River, Bangladesh. International Journal of Environmental Research, 4(2): 321-332.

Ahmed, A. U. and M. Reazuddin. 2000. Industrial pollution of water systems in Bangladesh. In: Rahman, A. A., S. Huq and G. R. Conway (eds.). Environmental system of surface water of Bangladesh. pp.175-178.

Akter, A. 2011.Peopleâs perceptions of environmental pollution in Mokesh Beel, Bangladesh. Department of Environment, E-16 Agargaon, Dhaka, Bangladesh.pp.1-14.

Alam, A. M. S., M. A. Islam, M. A. Rahman, A. Ahmed, S. Islam, K. S. Sultana and M. N. Siddique. 2004. Transport of toxic metal through the major river system of Bangladesh. Journal of Chemical Society in Pakistan, 26(3): 328-332.

Alam, M. J. B., Z. Muyen, M. R. Islam, S. Islam and M. Mamun. 2007. Water quality parameters along the rivers. International Journal of Environment Science and Technology, 4(1):159-167.

Alam, M. N., P. D. F. Elahi and M. D. Alam. 2006. Risk and water quality assessment overview of river Shitalakhya in Bangladesh. Academic Open Internet Journal, 19:1311-1316.

BBS (Bangladesh Bureau of Statistics). 2012. Bangladesh Population and Consensus 2011. Community Report Gazipur Zila.

BCAS (Bangladesh Centre for Advanced Studies). 2009. The state of Bangladesh water. Bangladesh center for advanced studies, Dhaka, Bangladesh.

Begum, A., M. N. Amin, S. Kaneco and K. Ohta. 2005. Selected elemental composition of the muscle tissue of three species of fish, Tilapia nilotica, Cirrhina mrigala and Clarius batrachus, from the fresh water Dhanmondi lake in Bangladesh. Food Chemistry, 93: 439-443.

Das, M., K. Ahmed, M. M. Islam, M. S. Akter, S. Islam and M. A. A. Mansur. 2011. Physicochemical properties of tannery and textile effluents and surface water of River Buriganga and Karnatoli, Bangladesh. World Applied Science Journal, 12: $152-159$.
DoE (Department of Environment). 1992. Annual Report. Ministry of Environment and Forest, Government of the People's Republic of Bangladesh.pp.10-25.

DWASA (Dhaka Water Supply and Sewerage Authority). 2011. Feasibility study for augmentation of water supply to Dhaka, Bangladesh, 1:94.

ECR (The Environment Conservation Rules). 1997. Ministry of Environment and Forest, Government of the People's Republic of Bangladesh.pp.4-45.

EQS (Environmental Quality Standard). 1997. Ministry of Environment and Forest, Department of Environment, Government of the Peopleôs Republic of Bangladesh.

Guven, K., C. Ozbay, E. Unlu and A. Satar 1999.Acute lethal toxicity and accumulation of copper in Gammarus pulex (L.) (Amphipoda). Turkey Journal of Biology, 23:513-521.

Islam, M. S., M. H. Kabir, S. A. Sifat, N. T. Meghla and T. R. Tusher. 2014. Status of water quality from the Padma river at Bheramara point of Kushtia in Bangladesh. Bangladesh Journal of Environmental Science, 27: 110-115.

IWM (Institute of Water Modeling). 2007. Draft thematic study. Regional water resources development status, Flood plan coordination organization, Dhaka.

IWRB (International Waterfowl Research Bureau). 1992. Action programme for the conservation of wetlands in South and West Asia. Northeast regional water resources development project (FAP 6), 1992. Draft thematic study. Regional water resources development status, Flood plan coordination organization, Dhaka.

Khaled, A. 2004. Heavy metal concentrations in certain tissues of five commercially important fishes from El-Mex Bay, Al-Exandria, Egypt. pp. 111 .

Khan, M. A. I., A. M. M. Hossain, M. E. Huda, M. S. Islam and S. F. Elahi. 2007. Physicochemical and biological aspects of monsoon waters of Ashulia for economic and aesthetic applications: Preliminary studies. Bangladesh Journal of Scientific and Industrial Research, 42(4): 377-396.

Malik, N, A. K. Biswas, T. A. Qureshi, K. Borana, and R. Virha. 2010. Bioaccumulation of heavy metals in fish tissues of a freshwater lake of 
Bhopal. Environmental Monitoring Assessment, 160: 267-267.

Meghla, N.T., M. S. Islam, M.A. Ali, Suravi and N. Sultana. 2013. Assessment of physicochemical properties of water from the Turag river in Dhaka City, Bangladesh. International Journal of Current Microbiology and Applied Sciences, 2(5): 110-122.

Mohiuddin, K. M., H. M. Zakir, K. Otomo, S. Sharmin and N. Shikazono. 2010. Geochemical distribution of trace metal pollutants in water and sediments of downstream of an urban river. International Journal of Environmental Science and Technology, 7: 17-28.

Mohuya, F. A., R. H. Bhuiyan and S. Hoque. 2010. Heavy metal contamination in GulshanBaridhara lake, Dhaka. Dhaka University Journal of Biological Science, 19(1): 53-61.

Mokaddes, M. A., B. S. Nahar and M. A. Baten. 2013. Status of heavy metal contaminations of river water of Dhaka metropolitan city. Journal of Environmental Science and Natural Resources, 5(2): 349-353.

Olaifa, F.E., A. K. Olaifa, A.A. Adelaja and A.G. Owolabi. 2004. Heavy metal contamination of Clarias gariepinus from a lake and fish farm in Ibadan, Nigeria. African Journal of Biomedical Research, 7: 145ї 148.
Quraishi, S.B., T. R. Choudhury, S.R. Khan and M.A. Mottaleb. 2010. Season and year wise distribution of some trace metals and anions in Gulshanlake, Bangladesh. Maejo International Journal of Science and Technology, 4(2): 337346.

Rahman, A.K.M.L., M. Islam, M.Z. Hossain and M.A. Ahsan. 2012. Study of the seasonal variations in Turag river water quality parameters. African Journal of Pure and Applied Chemistry, 6(10): 144-148.

SEHD (Society for Environment Human Development). 1998. Bangladesh Environment: Facing $21^{\text {st }}$ Century. Society for Environment Human Development (SEHD) Publications, Dhaka, Bangladesh.

Sumon, H. K. 2012. Comparative assessment of some chemical properties of Balu river water during wet and dry season. MS Thesis. Department of Environmental Science, Bangladesh Agricultural University (BAU), Mymensingh2202. 